\title{
The Effect of Government Expenditures in Mineral Industry Development and Value Added of Mineral in Indonesia
}

\author{
Hijir Ismail Adnin Rasyad \\ Ph.D Candidate, Graduate School of Economics \\ Hasanuddin University, Makassar \\ South Sulawesi, Indonesia \\ Muhammad Yunus Zain \\ Professor, Ph.D, Graduate School of Economics \\ Hasanuddin University, Makassar \\ South Sulawesi, Indonesia \\ Marzuki \\ Professor, Ph.D, Graduate School of Economics \\ Hasanuddin University, Makassar \\ South Sulawesi, Indonesia \\ Abdul Rahman Razak \\ Ph.D, Graduate School of Economics \\ Hasanuddin University, Makassar \\ South Sulawesi, Indonesia \\ DOI: $10.31364 / S C I R J / v 6 . i 7.2018 . P 0718543$ \\ http://dx.doi.org/10.31364/SCIRJ/v6.i7.2018.P0718543
}

\begin{abstract}
The development of minerals industry to get the added value of minerals in the long run according to Law no. 4 Year 2009 About Mineral and Coal Mining, can be realized in an industrial cluster, and its success is determined by the availability of mineral reserves, human resources availability, investment willingness and availability of electricity infrastructure, for government support.

The contribution of the government in the implementation of hilirisasi policy in Indonesia is manifested in the form of government expenditure in capital expenditure at the district level, where a mining business area (WUP) is located, so it can affect the increase of added value of minerals in Indonesia.

Direct government spending has a positive effect on the increase of added value of minerals in Indonesia, but indirectly, government expenditures have a significant effect on increasing mineral added value, through increased mining and industrial investment, increasing the number of mining workers, and increasing electricity infrastructure.
\end{abstract}

Keywords: value-added of minerals, mineral industry, government expenditure

\section{PRELIMINARY}

The issue mineral of value added that can be obtained from a mineral resource utilization, is increasing with the increase of science and technology. The issue, especially in countries with abundance of natural resources, including Indonesia.

In the past 10 years, Indonesia as a country with its abundance of natural resources, has been lacking significant added value to mining and mining business fields, thus contributing to Indonesia's economic growth is also less significant (Financial Services Authority, 2015, BPS in Suyanto, 2011).

In fact, Indonesia is classified as a fairly productive country in the export of minerals, especially nickel, iron, copper and bauxite commodities, but in general in the form of raw minerals, thus providing less value for economic growth (Keynes, 1935 ).

However, on the other hand Indonesia is also listed as a country with imports of semi-finished materials (concentrates) and finished materials (metals) large enough to meet the needs of industry, construction, energy and telecommunications in the country (Ministry of Industry, 2017).

Considering the above phenomena, the low added value of Indonesian minerals, among others, is due to the high export of crude minerals, followed by the import of semi-metal and metal materials which are also quite high, and caused by the limitations of the mineral industry in the country.

Auty (2003) states that for the development of natural resource potential in developing countries, industrialization is the key 
to both domestic and export markets, which has a positive impact on economic growth. However, for its development, Government support (Alayi, 2005) is needed to encourage mining and industrial investment in the country, to improve the ability of mining human resources and to increase electricity infrastructure in order to realize the added value of minerals which ultimately has implications for economic growth (Pangestu, 1999 in Suyanto, 2011; Tambunan, 2006).

Following is the data of contribution of mining and quarrying business field in mining business area (WUP) in Indonesia to PDRB Kabupaten, where a WUP is located, refresentative for nickel, iron, copper and bauxite commodities (Table 1).

Table 1

Value Added field of Mining and Quarrying Business to PDRB of District in Indonesia

\begin{tabular}{|c|l|c|l|l|l|}
\hline \multirow{2}{*}{ No. } & \multirow{2}{*}{$\begin{array}{c}\text { Mining Business } \\
\text { Of Region (WUP) }\end{array}$} & \multirow{2}{*}{ Commodities } & \multicolumn{3}{|c|}{$\begin{array}{c}\text { Added Value of Mining Business Field and Excavation } \\
\text { on PDRB of District } \\
\text { (Millions Rupiah) }\end{array}$} \\
\cline { 5 - 7 } & & & \multicolumn{2}{|c|}{2011} & \multicolumn{1}{c|}{2015} \\
\hline 1 & District of Kolaka & Nickel & $5,101,045.19$ & $7,261,880.40$ & $7,357,716$. \\
\hline 2 & District of South Konawe & Nickel & $980,751.37$ & $1,285,068.99$ & $1,545,704.18$ \\
\hline 3 & District of East Luwu & Iron & $7,029,085.57$ & $7,706,179.57$ & $8,831,737.22$ \\
\hline 4 & District of Solok & Iron & $360,217.30$ & $416,374.68$ & $452,713.80$ \\
\hline 5 & District of Toli-Toli & Copper & $58,511.40$ & $71,180.40$ & $91,089.30$ \\
\hline 6 & District of Pacitan & Copper & $746,654.40$ & $497,298.50$ & $536,233.40$ \\
\hline 7 & District of Ketapang & Bauxite & $1,765,134.40$ & $1,707,475.53$ & $1,569,210.94$ \\
\hline 8 & District of Kotawaringin & Bauxite & $501,523.46$ & $898,691.92$ & $719,109.19$ \\
\hline
\end{tabular}

Source: Central Bureau of Statistics, 2011,2013,2015

Table 1 above shows the added value of minerals on nickel, iron ore, copper and bauxite commodities through the contribution of the mining and quarrying field to the district GDP in Indonesia, where the mining business area (WUP) is located. In the table, it appears that WUP Nickel Kab. Kolaka Southeast Sulawesi Province and iron ore WUP Kab. East Luwu South Sulawesi Province has added value of mineral which is much higher than other WUP. This happens because both WUPs are available in the mineral industry (PT Aneka Tambang tbk in Kolaka and PT Vale Indonesia in East Luwu District) with an average contribution of about $60 \%-65 \%$ of its GRDP, it becomes important to realize the mineral industry in other WUP in order to increase the added value of minerals.

So interesting and important is the value of mineral value added above, to increase the contribution of mining and excavation field to PDRB Kabupaten in Indonesia, so that this research is done with approach of economics.

The increase of the added value of minerals above is realized due to higher price increase, where the product of processing is higher than the raw mineral, and the refined product is higher in price than the processing product (Data and Information Center of Energy and Resource of Mineral, 2012).

The importance of the issue of increasing the added value of minerals for economic growth above, especially for the mining business field and excavation of the Regency GDP, so that it is issued Law no. 4 of 2009 on mineral and coal mining, and is a form of transformation of mineral industry policy in Indonesia, from upstream (mineral upstream industry) with crude mineral output to downstream minerals industry with concentrate and metal output, which is expected to provide added value for economic growth in the long term (Adam, 2014).

However, until the end of 2013 most of the existing mining business units in Indonesia have not been able to implement the policy of increasing the added value of minerals (Article 102 of Law No.4 of 2009), and conduct mineral processing / purification either in its own environment or through IUP / Other IUPK (Article 103 of Law No. 4 Year 2009), whereas the mineral downstream policy must be implemented since early 2014.

Implementation of mineral industry development to increase the added value of minerals in Indonesia, as above until now can not be realized properly, partly due to limited mining investment, limited human resources and limited electricity infrastructure, so the pattern of mineral industry development that requires every business holder mining for processing and refining itself is difficult to implement (Article 20 paragraph 1 of Law No.4 of 2009).

Therefore, the development of minerals industry through cooperation among mining business holders in a mining business area (WUP) can be realized with a cluster of mineral industry (Porter, 2000, Porter, 1998) is one of the right solutions and has empirically been applied and successful in some other countries (Charles, 2015).

Furthermore, the success of a mineral industry cluster is determined by its input factor, which consists of natural resource availability, human resource availability, availability of capital and availability of infrastructure. In addition, it is also determined by the ability of local suppliers, demand conditions, which include local contexts, which encourage the precise form of an investment over government support, and is expressed in the form of the Porter Diamond Model (Porter, 2000, 1998). 
Assuming that the availability of natural resources in Indonesia is abundant in all these commodities, the willingness of mining and industrial investment for the development of mineral industry in a mining business area (WUP) has a direct effect on increasing GDP (Khudler, 2014; Maslyuk and Dinusha, 2012), even investments originating from FDI for mining have an effect on increasing the mining and excavation field (Salebu, 2014).

The availability of human resources as measured by the number of mining workers with a good level of education and skills, has an effect on increasing the added value of mining and excavation (Todaro, 2000).

In addition, the availability of electricity infrastructure that limits the development of the mineral industry in Indonesia, becomes important (Ministry of Industry, 2017). And, the support of electricity infrastructure is important for the minerals industry, even the limitation of such infrastructure is an obstacle to the improvement of economic growth (Ndulu et al, 2005 in Maqin, 2011).

However, to support the willingness of mining and industrial investments, the availability of human resources and the availability of the above electricity infrastructure, fiscal policy is required through government spending implemented in the form of capital expenditures per district, directly and indirectly positively influencing the increase of added value of minerals (Sukirno, 2000).

\section{THEORETICAL REVIEW}

Industry as an economic activity that can create added value (Hasibuan, 2004). The added value (value added) as an added value of a combination of factors of production and raw materials in the production process, which is formulated as the value of production (output) minus the cost between (Static Center).

In fact, gross domestic product (GDP) can also be interpreted as the amount of added value generated by all business units within a given country, and is the sum of the value of final goods and services produced by all economic units.

Then, Smith (1977), states value added is the difference between the final product and the sacrifices that have been made. And Hayami Y, et al (1987) expresses the added value as the growth of the value of a product (commodity) because of the processing in a production, so it is a function of the production capacity, the amount of raw materials, the amount of labor, the wage of labor, the price of output, raw material prices and other inputs.

Furthermore, Rudenno (2004) states that the added value of the economy (economic of value added) of minerals will vary, depending on the type of minerals. Nickel in 1 ton is only $2 \%$, and through the process of metallurgical nickel in ferronickel levels can reach $10 \%$ - 30\%. However, in terms of cost (process cost), the amount of cost required is determined by the type of minerals, mining techniques, technology and energy sources used.

Referring to the theoretical understanding of the added value above, the increase of added value of minerals can only be done and obtained the result through processing and mineral purification process (article 1, paragraph 6 of Law No. 4 Year 2009), where the processing and purification of minerals as an activity to improve the quality of minerals and / or coal as well as to utilize and obtain mineral follow-up (Article 1 verse 20 of Law No. 4 Year 2009).

However, the increase of the added value of minerals above can only be realized, among others, through increased investment in mining and industry, improvement of electricity infrastructure, which is totally influenced by government adventure in the form of capital expenditures.

\section{Availability of Electricity Infrastructure}

Potter (2000), states the various types of infrastructure needed in an industrial cluster, whether physical infrastructure, administrative infrastructure or science and technology infrastructure.

Physical infrastructure such as the availability of roads, ports and electric power is the basic infrastructure needed for the development of a mineral industry (Ministry of Industry, 2017). Meanwhile, other supporting infrastructure, including the availability of a good industrial cluster administration system so that all relevant stakeholders in industrial cluster development can be consistent and agreed together to encourage the establishment of an industry.

However, the Ministry of Industry (2017) stated that Indonesia still needs 1,020 MW of power plant infrastructure to develop the nickel industry, so that it can run effectively and efficiently, the use of energy sources derived from renewable energy (Miskelly, 2004) is needed.

The above mentioned means that the source of electrical energy needed is a source of energy derived from Non PLN, such as hydropower (hydropower), microhydro power plant (PLTMH), solar power plant (PLTS), and other efficient generators, because of the advantages of the mineral industry, one of which is determined by the utilization of its energy (Triswan, 2011; Blomber, 2007).

\section{Availability of Human Resources}

The availability of human resources is an essential enough factor in the cluster of mineral industry development, whose quality is demonstrated by the level of education, skills and basic knowledge in sufficient quantities in a mining business area (WUP).

Todaro (2000), said that human capital is an important factor in increasing the economic output of a country, therefore investment for human resource improvement becomes very important.

The well-being of a State besides determined by the importance of economies of scale is also determined by the formation of skill and quality of human resources (Smith, 1776). The second factor is that until now has become a major concern in various countries that are believed to affect the ability of a nation in view of economic opportunities, labor productivity and employment opportunities. 
Then, Simanjuntak (1989), states that education is even strongly related to the increase of economic growth for a long period of time. The level of education held by a person is influenced by non-market factors (non-economic), but generally can be viewed as a result determined by the combination of the forces of demand and supply to education.

The demand factor for education is far more important than the supply factor (Todaro, 1994). On the demand side, among others, affects the total population of education as a hope for a more educated student to find a better income-earning job in the modern sector in the future. The demand for education is an indirect demand or derived demand, and behind the demand for education there is a more fundamental demand, namely the demand for high-income employment in the modern sector.

Furthermore, education will not only give birth to quality human resources, knowledge and skills and master technology, but also to foster a healthy and conducive business climate for economic growth (Schweke, 2004). Furthermore, education is an investment decision, in which to build human capital, generally only can be obtained through a level of education in the hope of getting better job opportunities and income (Santoso, 2012).

O'sullivan (2006), also stated that an increase in human capital will increase productivity and income levels that will have an impact on increasing economic growth.

The availability of human resources determines the effectiveness and efficiency of a mineral industry development activity and increased value-added minerals for mining and quarrying fields.

Meier, et.al (2005) in Aimon (2012), states that human capital has a direct contribution to the creation of national wealth, where the higher the level of knowledge and skills possessed, the easier it is for individuals to know and apply a technological advance.

\section{Availability of Mining and Industrial Investment}

The availability of capital is essential for the operation of a mineral industry cluster. Jogianto (2008), stated that Investment as an investment on certain assets to obtain more value in the future. And, is the mobilization of resources for future income (Makmum, 2000).

Furthermore, Investment is considered as a form of capital formation, meaning that the profit function in the economy, where the government is not an important investor or participant, and foreign investment can be considered as capital formation by a company to a foreign country (Smith, 1776 ), is not only important for the development of the minerals industry, but also can promote economic growth (Sollow, 1956), and has a linear relationship with production (Napier, 1981).

In fact, Smith (1776), also states that economic development requires foreign capital. The division of labor can only be done after the accumulation of capital (capital accumulation). The government should not interfere with trade and investment activities, and should always seek a free market. It is the market mechanism that should determine how foreign investment is performing and encourage economic growth. The broadest possible freedom of competition between domestic and foreign business actors in order to make the free market truly efficient.

However, Keynes (1935), states the demand for investment is inversely proportional to the interest rate. If the interest rate is high, the person will keep the money in the bank rather than invest it, because the expected return expected to be obtained from the bank interest is greater than the capital investment, consequently the demand for investment will be reduced. The high interest rates reflect also the high credit, thereby reducing the enthusiasm of investment among entrepreneurs.

In addition, Keynes (1935) also stated that government expenditures and bank credit have a positive effect on investment, and subsequently investment has a positive impact on economic growth (Tambunan, 2003).

Furthermore, Jorgenson, et al (1987), states that the United States economy in the period 1948 - 1979, as much as 46\% economic growth caused by capital formation $31 \%$ caused by the growth of labor and human capital and $24 \%$ by technological advances.

Furthermore, Lubis et al (2015), stated that mining sector investment is generally dominated by foreign investment. And, Jefry Batara Salebu (2014), even stated that FDI has a positive and significant effect on GDP, particularly mining and quarrying business fields.

\section{Government Expenditures}

Government spending reflects a government policy (Guritno, 1999), where the theory of government spending by economists, is divided into Wagner's legal model and theoretical model of Peacock and Wiseman.

Wagner (19th century), which states that in an economy if per capita income increases, then the relative expenditure of government will increase mainly because the government must regulate the relationships that arise with society, industry, externalities and market failures.

Then, Peacock and Wiseman (1961), the best theory of government expenditure development is based on government revenue and expenditure analyzes. The government is always trying to increase its expenditure from tax revenues, whereas people do not like the huge tax payments, so the constraints are also for the government to increase the tax.

Economic growth causes tax collection to increase, although tax rates are unchanged and increased tax revenues lead to increased government spending. Larger tax levies, causing private investment to be reduced (displacement effect), so that private activity turned into government activities, where the government borrowed funds from abroad. After the disturbance is resolved, the obligation to pay off the debt and pay interest.

Furthermore, the increasing government expenditure is not only because the GNP increases, but because of the new obligations. The further consequence is the tax does not decrease back to its original level even though the disruption has ended. In addition, there are still many new government activities visible after the war and are called inspection effect. The existence of social disturbance as well, will cause the concentration of activities into the hands of government previously implemented by the private, referred to as the effect of concentration (concentration effect). 
Given the above three securities, it causes the increase of government activity, so that after the war the tax rate does not fall back to pre-war level. On the other hand, the theory of the development of government spending of Peacock and Wiseman versions is not a line, but like a ladder. Under normal circumstances, $t$ to $t+1$, then government spending on GNP increases. In the wake of the war, government spending increases by $\mathrm{AB}$ and then increases as shown in the $\mathrm{BC}$ segment. After the war finished in year $t+1$, government spending did not decrease to $\mathrm{P}$. This is because after the war, the government needed additional funds to recover government loans used in development financing.

The increase in tax rates above, is understood by the public, so the level of tax tolerance increases and the government can levy larger taxes, without causing disruption in the community. Graphically, the development of government spending of Peacock and Wiseman versions is not a pattern like the smooth-seated positive curve as implicit in Rostow and Musgrave's opinion, but is positively positively shaped like a ladder.

However, Bird, 1971 in Guritno (1999), criticizes the hypothesis proposed by Peacock and Wiseman, and states that during social disturbances, there is a diversion of government activity from expenditure prior to disruption to expenditure associated with the disorder. This will be followed by an increase in the percentage of government spending on GDP. And, after the disruption, the percentage of government spending on GDP will decline slowly back to its original state. Switching effects are symptoms in the short term, but they do not occur in the long term.

Then, Rostow and Musgrave (1999), which states the model of development of government spending with three stages of economic development. The initial stage is an important and strategic stage for the government, where large government investment is due to the provision of infrastructure, such as to build mining infrastructure. The government expenditure aims to boost economic growth with increased private financing at a later stage.

Musgrave (1999) also states that in a development process, private investment in percentage of GDP is getting bigger, and the percentage of government investment in percentage of GNP will be smaller. At a further economic level, Rostow states that economic development, where government activity shifts from providing infrastructure to spending on social activities includes education and public health services programs.

The theory of development of the role of government is the view that arises from the observation of economic development by many States, but not based on a particular theory (Musgrave and Rostow, 1999).

Government spending is part of fiscal policy by increasing aggregate spending on goods and services and the addition of investments (Keynes, 1936). This means that government spending directly affects investment and consumption increases.

Then, Sukirno (2000), states that government spending is a government action that regulates the course of the economy. One of the fiscal policies undertaken by altering state revenues and expenditures, a government policy that makes changes in the field of taxation (T) and government spending $(\mathrm{G})$ in order to influence aggregate spending / demand in the economy. The policy is for economic stability, expanding employment opportunities, enhancing economic growth and equity in equity distribution. Therefore, the increase in government expenditure affects the increase in the number of mining workers and directly affects the added value (economic growth).

Furthermore, Nangarumba (2016), stated that fiscal policy is one of the macro policies whose authority is in the hands of the government, and is represented by the Ministry of Finance, in accordance with Law no. 17 of 2003 on State Finances, stating that the President grants the power of financial management and state assets to the Minister of Finance and separated state assets. Fiscal policy generally represents the government's choices in determining the amount of expenditure and the amount of revenue explicitly used to influence the economy.

Government intervention is still essential if the economy is fully regulated by activities in the free market, not only does the economy not always reach full employment levels, but also the stability of economic activity can not be realized. Keynes in Sukirno (2000) states that the fluctuations in the wide economic activity from one period to another have serious implications for employment, unemployment and price levels, where government spending and increased investment can increase economic growth.

Further, Boediono (1999), states that government spending consists of three main items, namely government spending on goods and services purchases, government expenditures for staff salaries and government expenditures for transfer payments. Transfer payments are not purchases of goods or services by the government on the merchandise, but direct government grants to citizens that include subsidy payments or direct assistance to various groups of society, pension payments, interest payments for government loans to the public. Economically, the transfer payment has the same status and influence as the salary post, although the administration is different.

Next, John Freebairn (2012), states that government spending in Australia to support infrastructure expansion of transport, physical infrastructure, social infrastructure in remote mining areas at the time of the mining boom has given the Government an increase of $6 \%$. This means that government spending on infrastructure improvements indirectly affects added value.

Then, Ismail (2011), analysis of economic development and fiscal policy with Wagner's theory and Keynesian law using econometric model, and found that Indonesia's economic growth is influenced by government spending, in the form of work expenses.

Furthermore, Uchenna and Osabuchien (2012), Macroeconomic Policy in Nigeria, with Government expenditure policy instruments, has responded to fiscal decentralization policies, political instability and economic growth. This shows the effect of government spending on encouraging added value.

Furthermore, the empirical study of fiscal policy in some developing countries, the impact of distribution is the analysis for certain components of government expenditure such as primary, secondary, tertiary educational programs, expenditures to support agricultural infrastructure to be able to produce, have been undertaken by governments derived from distributed tax revenues (Masood Mashkoor Siddiqui and Abdul Malik, 2011).

Subsequently, an empirical study of copper mines in Chile that has contributed to the development of the State as a 
consequence of the Chilean Government which has allocated government spending for the development of an export-oriented domestic transport infrastructure, has made mining more modern, efficient and competitive (Arellano, 2012). This means that government spending on infrastructure improvements has an effect on the more efficient mining, which will benefit from efficiency and generate added value for mining and excavation fields at the district level.

Furthermore, empirical studies of the effects of natural resource extraction both locally and regionally, where government spending has encouraged the management of natural resources for well-being, society (Cust and Poelhekke, 2015), and the government's fiscal policy operations significantly influence the direction of economic resources work (Keyness, 1936).

Furthermore, Partowidagdo (1999) in Wiriosudarmo (2000), said government expenditures for mining and industrial infrastructure development could affect the development of the minerals industry.

\section{METHODOLOGY OF RESEARCH}

Research on the influence of government expenditure in the development of mineral industry (mineral industry cluster pattern) to increase added value of minerals in Indonesia, using quantitative method with structural equational modeling (Kusnadi, 2008) with reference to the relation between variable dependent $\left(\mathrm{y}_{4}\right)$, interpening variables $\left(\mathrm{y}_{1}, \mathrm{y}_{2}, \mathrm{y}_{3}\right)$ which are endogenous and independent variables (x) which are exogenous variables, are graphically shown in Fig.1.

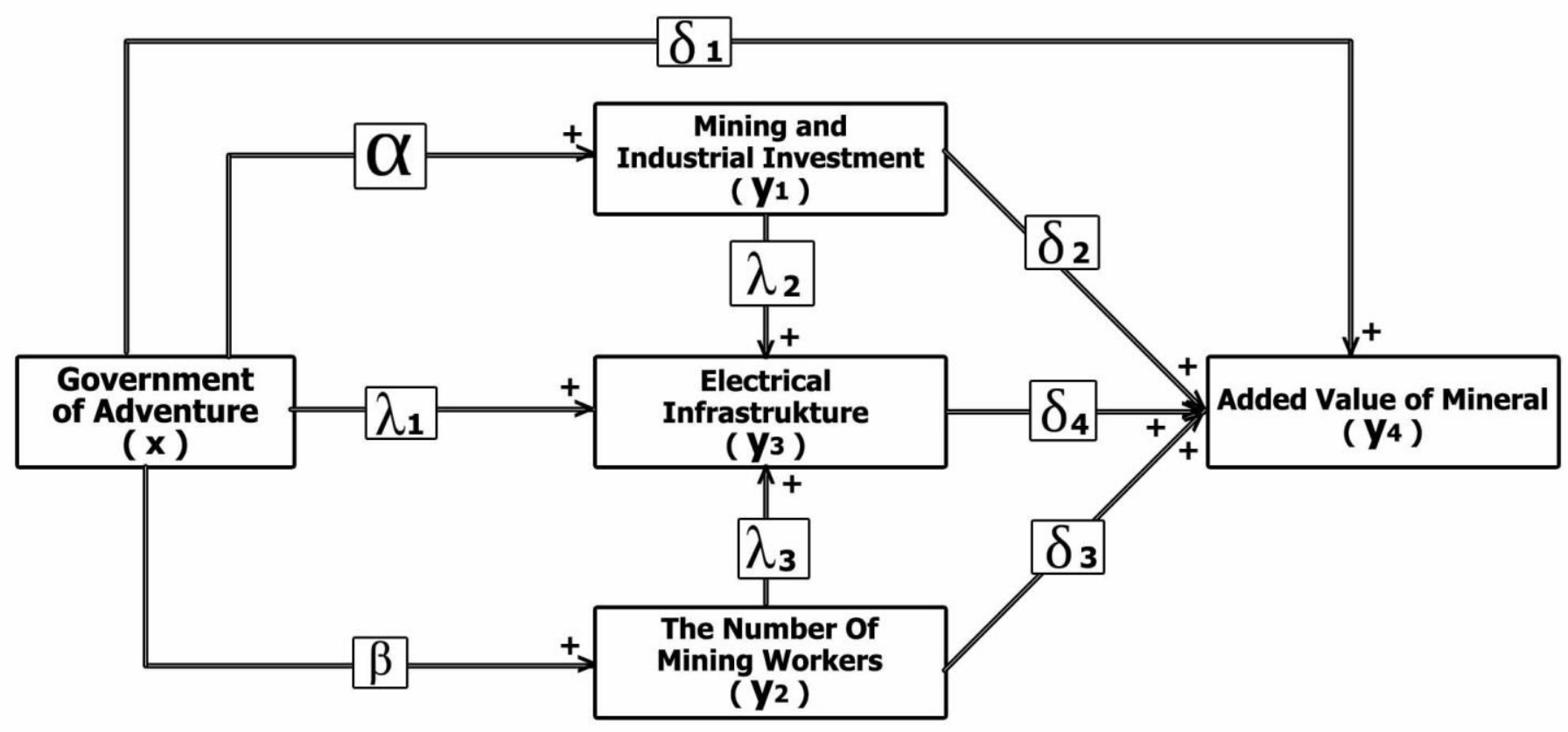

Figure 1

The research model influences government expenditure in the development of mineral industry and value added minerals in Indonesia

The framework of research conception as explanation of the relationship between variables in figure 1, can be expressed in the simultaneous equation for linear regression estimation with the following functions:

$\mathrm{y}_{1}=f\left(\mathrm{x}, \mathrm{u}_{1}\right)$

$\mathrm{y}_{2}=f\left(\mathrm{x}, \mathrm{u}_{2}\right)$

$\mathrm{y}_{3}=f\left(\mathrm{y}_{1}, \mathrm{y}_{2} ; \mathrm{x}_{1} \mathrm{u}_{3}\right)$

$\mathrm{y}_{4}=f\left(\mathrm{y}_{1}, \mathrm{y}_{2}, \mathrm{y}_{3} ; \mathrm{x}_{1} \mathrm{u}_{4}\right)$

Where :

$\mathrm{y}_{4}$ : Value added field of mining business and excavation level district, measured in

millions of Rupiah

$\mathrm{y}_{3}$ : Electricity infrastructure, measured in MW (Megawatt)

$\mathrm{y}_{2}$ : The number of mining workers in a WUP, measured in person

$\mathrm{y}_{1}$ : Mining and industrial investment, measured in millions of rupiah

Then, from equation 1 - 4 above, for the formulation of non linear equations (Cobb Douglass) can be expressed by the following equation: 


$$
\begin{aligned}
& Y_{1}=e^{\alpha_{0}+\mu_{1}} X^{\alpha_{1}} \\
& Y_{2}=e^{\beta_{0}+\mu_{2}} X^{\beta_{1}} \\
& Y_{3}=e^{\gamma_{0}+\mu_{3}} X^{\gamma_{1}} Y_{1}^{\gamma_{2}} Y_{2}^{\gamma_{3}} \\
& Y_{4}=e^{\lambda_{0}+\mu_{4}} X^{\lambda_{1}} Y_{1}^{\lambda_{2}} Y_{2}^{\lambda_{3}} Y_{3}^{\lambda_{4}}
\end{aligned}
$$

$\alpha_{0}, \beta_{0}, \gamma_{0}$ and $\theta_{0}$ are Constants, $\alpha_{1}, \beta_{1}, \gamma_{1}-\gamma_{3}$ and $\lambda_{1}-\lambda_{4}$ are respectively parameters to be estimated and $\mu_{1}-\mu_{4}$ are error terms. The functional equation for reducing form in simultaneous equation model (SEM) are as follows :

$$
\begin{aligned}
& Y_{1}=\alpha_{0}+\alpha_{1} X+\mu_{1} \\
& Y_{2}=\beta_{0}+\beta_{1} X+\mu_{2} \\
& Y_{3}=\lambda_{0}+\lambda_{1} X+\mu_{3} \\
& Y_{4}=\delta_{0}+\delta_{1} X+\mu_{4}
\end{aligned}
$$

Where:

$$
\begin{aligned}
& \alpha_{0}=\alpha_{0} ; \alpha_{1}=\alpha_{1} ; \mu_{1}=U_{1} \\
& \beta_{0}=\beta_{0} ; \beta_{1}=\beta_{1} ; \mu_{2}=U_{2} \\
& \lambda_{0}=\gamma_{2} \alpha_{0}+\gamma_{3} \beta_{0}+\gamma_{0} \\
& \lambda_{1}=\gamma_{2} \alpha_{1}+\gamma_{3} \beta_{1}+\gamma_{1} \\
& \mu_{3}=\gamma_{2} U_{1}+\gamma_{3} U_{2}+U_{3} \\
& \delta_{0}=\left(\lambda_{2}+\gamma_{2} \lambda_{4}\right) \alpha_{0}+\left(\lambda_{3}+\gamma_{3} \lambda_{4}\right) \beta_{0}+\lambda_{4} \gamma_{0}+\lambda_{2} \\
& \delta_{1}=\left(\lambda_{2}+\gamma_{2} \lambda_{4}\right) \alpha_{1}+\left(\lambda_{3}+\gamma_{3} \lambda_{4}\right) \beta_{1}+\lambda_{4} \gamma_{1}+\lambda_{1} \\
& \mu_{4}=\left(\lambda_{2}+\gamma_{2} \lambda_{4}\right) U_{0}+\left(\lambda_{3}+\gamma_{3} \lambda_{4}\right) U_{2}+\lambda_{4} U_{3}+U_{4}
\end{aligned}
$$

\begin{tabular}{|c|c|c|c|c|c|c|c|}
\hline No & WUP & Influence & Estimasi & Probability & SE & $\mathbf{C R}$ & Note : \\
\hline \multirow[t]{9}{*}{1} & \multirow[t]{9}{*}{$\begin{array}{l}25 \text { of } \\
\text { WUP }\end{array}$} & $\mathrm{x} \ldots \ldots \ldots \ldots \ldots>\mathrm{y}_{4}$ & 2.3804 & 0.0966 & 0.2289 & 1.6617 & \\
\hline & & X ----------> Y $Y_{1}$ & 1.4756 & $* * *$ & 0.3339 & 4.4018 & $*$ \\
\hline & & $x \ldots \ldots \ldots \ldots>y_{2}$ & -0.1048 & 0.5811 & 0.19 & -0.5518 & \\
\hline & & $\mathrm{x} \ldots \ldots \ldots \ldots \ldots \mathrm{y}_{3}$ & 0.7441 & 0.0224 & 0.3258 & 2.2841 & $*$ \\
\hline & & $\mathrm{y}_{1} \ldots \ldots \ldots \ldots>\mathrm{y}_{3}$ & 0.0687 & 0.333 & 0.071 & 0.9681 & \\
\hline & & $\mathrm{y}_{2} \ldots \ldots \ldots \ldots>\mathrm{y}_{3}$ & -0.2868 & 0.0021 & 0.931 & -3.0815 & $*$ \\
\hline & & $\mathrm{y}_{1} \ldots \ldots \ldots \ldots>\mathrm{y}_{4}$ & 0.237 & $* * *$ & 0.0468 & 5.0635 & $*$ \\
\hline & & $\mathrm{y}_{2} \ldots \ldots \ldots \ldots>\mathrm{y}_{4}$ & 0.2842 & 0.0125 & 0.0593 & -2.499 & $*$ \\
\hline & & $\mathrm{y}_{3} \ldots \ldots \ldots \ldots>\mathrm{y}_{4}$ & 0.284 & $* * *$ & 0.0607 & 4.679 & $*$ \\
\hline
\end{tabular}

\section{RESULT AND DISCUSSION}

To analyze the effect of government expenditure in the form of capital expenditure in the development of mineral industry and value added minerals in Indonesia, a simultaneous linear regression analysis is used, which estimates the magnitude of direct and indirect effects.

In the linear regression analysis simultaneously, the endogenous variables of the model consist of mining and industrial investment $\left(\mathrm{y}_{1}\right)$, number of mining workers with senior secondary education $\left(\mathrm{y}_{2}\right)$, electricity infrastructure $\left(\mathrm{y}_{3}\right)$ and mineral added value $\left(\mathrm{y}_{4}\right)$. And, the exogenous variable is government expenditure $(\mathrm{x})$.

The results of the research with linear regression analysis in sumultan, showed the model matching test with $\mathrm{p}>0.05$, mean the model has been suitable in the analysis, so there is no difference between theoretical model and empirical data.

Table 2

The result of simultaneous linear regression estimation on mining and industry investment function $\left(\mathrm{y}_{1}\right)$, function of the number of mining worker with senior high school education level $\left(\mathrm{y}_{2}\right)$ and electricity infrastructure function $\left(\mathrm{y}_{3}\right)$

\footnotetext{
* Signifikan : $\alpha<0.05$
}

Table 2 above shows that from 9 directions the influence of variables relationship, found as much as 6 direction influence significant variable relation $(\mathrm{p}<0.05)$. The influence of the increase of government expenditure $(\mathrm{x})$ on the increase of mining and industrial investment $\left(\mathrm{y}_{1}\right)$, the effect of the increase of government expenditure $(\mathrm{x})$ on the improvement of electricity infrastructure $\left(\mathrm{y}_{3}\right)$, the influence of the increase of the number of mining workers of senior high school level and above $\left(\mathrm{y}_{2}\right)$ on the 
increase of mining and industrial investment $\left(\mathrm{y}_{1}\right)$ on the increase of added value of minerals $\left(\mathrm{y}_{4}\right)$, the influence of the increase in the number of senior high school $\left(\mathrm{y}_{2}\right)$ to increase the added value of minerals $\left(\mathrm{y}_{4}\right)$, and the effect of increasing electricity infrastructure $\left(\mathrm{y}_{3}\right)$ on the increase of added value of minerals $\left(\mathrm{y}_{4}\right)$.

Table 3

The value of the influence of the relationship between variables directly or indirectly in 25 Mining Business Areas (WUP)

\begin{tabular}{|c|c|c|c|c|}
\hline \multirow[t]{2}{*}{ No } & \multirow{2}{*}{$\begin{array}{c}\text { Mining Business } \\
\text { Of Region (WUP) }\end{array}$} & \multirow[t]{2}{*}{ Estimated } & \multicolumn{2}{|c|}{ Estimated Value } \\
\hline & & & direct & Undirect \\
\hline 1 & 25 of WUP & $\mathrm{x} \ldots \ldots \ldots>\mathrm{y}_{4}$ & 0.3804 & \\
\hline & & by $\mathrm{y}_{1}$ & & 0.3497 \\
\hline & & by $\mathrm{y}_{2}$ & & -0.01 \\
\hline & & by $y_{3}$ & & 0.02976 \\
\hline & & $\mathrm{y}_{1} \ldots \ldots \ldots>\mathrm{y}_{4}$ & $0.2370 *$ & \\
\hline & & $\mathrm{y}_{2} \ldots \ldots \ldots>\mathrm{y}_{4}$ & $0.2842 *$ & \\
\hline & & $\mathrm{y}_{3} \ldots \ldots \ldots>\mathrm{y}_{4}$ & $0.2840^{*}$ & \\
\hline & & $\mathrm{y}_{1}$ by $\mathrm{y}_{3}$ & & 0.0195 \\
\hline & & $\mathrm{y}_{2}$ by $\mathrm{y}_{3}$ & & -0.0976 \\
\hline
\end{tabular}

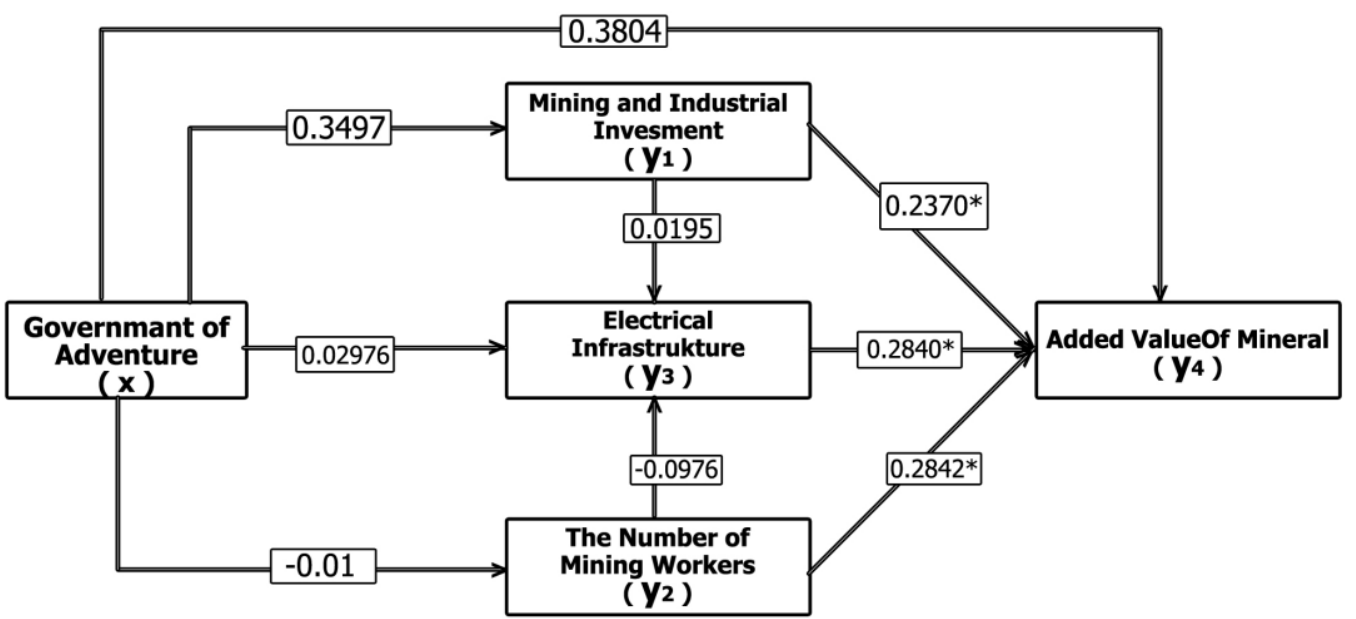

Figure 2

The result of linear regression estimation simultaneously on the effect of government expenditure (x) on the added value of minerals $\left(\mathrm{y}_{4}\right)$ directly, and indirectly through mining and industrial investment $\left(\mathrm{y}_{1}\right)$, the number of mining workers $\left(\mathrm{y}_{2}\right)$ and through electricity infrastructure $\left(\mathrm{y}_{3}\right)$

Figure 2 shows that government expenditure in the form of district capital expenditure (x) directly positively affects the increase of mineral added value in Indonesia $\left(\mathrm{y}_{4}\right)$, with an estimated value of 0.3804 .

However, the increase of the added value of minerals in Indonesia $\left(\mathrm{y}_{4}\right)$ as the effect of the above increase in government expenditure $(\mathrm{x})$ above, can be indirectly implemented through increased investment in mining and industry $\left(\mathrm{y}_{1}\right)$ with an estimated value of 0.3497 and implications for improvement value added minerals $\left(\mathrm{y}_{4}\right)$ significantly with an estimated value of 0.2370 .

Furthermore, the increase in government expenditure $(\mathrm{x})$ to encourage the increase of added value of minerals $\left(\mathrm{y}_{4}\right)$ can also be done through increasing the number of upper and lower secondary labor $\left(\mathrm{y}_{2}\right)$ workers with an estimated value of -0.01 , which implies significant increases in added value of minerals estimate of 0.2842 .

Furthermore, the increase in government expenditure $(x)$ to encourage the increase of added value of minerals $\left(y_{4}\right)$ can then be done through an increase in the amount of electricity infrastructure $\left(\mathrm{y}_{3}\right)$ with an estimated value of 0.02942 , which implies a significant increase in added value of minerals with an estimated 0.2940.

\section{CONCLUSION}

The development of mineral industry in a mining business area (WUP) aims to obtain the added value of minerals, and implies the increasing contribution of mining and quarrying field to the PDRB of regency in Indonesia in the long term.

Increased government expenditures in the form of capital expenditures indirectly have a significant effect on increasing the added value of minerals, through increased investment in mining and industry, through increasing the number of mining workers 
of senior high school and above, and by improving electricity infrastructure.

\section{REFERENCES}

Adam, Luqman, 2014, Kebijakan Mineral dan Batubara di Indonesia, Pusat Kajian DPR RI, Ekonomi dan Kebijakan Public

Aimon, 2012, Produktivitas, Investasi Sumberdaya Manusia, investasi fisik, Kesempatan Kerja terhadap Kemiskinan dan Pertumbuhan Ekonomi di Indonesia, Jurnal Kajian Ekonomi, Vol 1, 2012

Alayi, M.A, 2005, The Resources Curse Effect, Resources rich countries and weak Institutions

Arellano, 2102, Copper Mining and its impact on Chile’s dev, Central Bankof Chiles

Auty, R.M, 2003, National resources, models and sustainable development

Badan Pusat Statistik Tahun 2009 - 2014

Blomber, Jefri, 2007, Esai tentang ekonomi industri aluminum, Lulea Univ of technology, Swedia

Charles, Vincent, 2015, Mining cluster development in Peru: learning from theinternational best practice. Journal of applied environment and biological science 5

Cust and Poelhekke, 2015, The local economic impacts of natural resources extraction, annual review of resources economics

Fredbaim, 2012, Mining booms and government budget, the Australian journal of agricultural and resources economics, 56

Guritno, Mangkusubroto, 1994, Ekonomi public edisi 3, Yogyakarta, BPFE

Hasibuan, 2004, Ekonomi Industri, persaingan , monopoli dan regulasi, Univ Indonesia

Hayami, et al, 1987, Agricultural marketing and processing in upland Java, A prespective from Sinda Village Coarse grains, Univ Al Azhar

Ismail, Rifky 2011, Assessing economic growth and fiscal policy in Indonesia, east west journal economica and business

Jogiyanto, Hartono, 2008, Teori portopolio dan analisis Industri, BPFE, Yogyakarta

Jomgenson,Dale 1991, Productivity and economic growth, National bureau of economic research, univ of Chicago press

Keynes, JM, 1936, The general theory of employment, Interest and money, New York, Harcourt Brace

Khuder, Altain 2014, Impact of the global iron ore sector, stichting onderzoek multinationale ondermemingen (SOMO)

Kusnadi, 2008, Model-model persamaan structural, Alfabeta, Bandung

Makmum dan Akhmad Yasin, 2003, Pengaruh Investasi dan tenaga kerja terhadapPDB sektor pertanian, jurnal kajian ekonomi dan keunagan, Vol 7 No. 3 September

Maslyuk and Dharmaratna, 2012, Impact of shocls on Australia Coal mining, Department of economics, Monash Univ

Maqin,Abdul 2011, Pengaruh kondisi infrastruktur terhadap pertumbuhan ekonomi Jawabarat, Trikonomika, Vol 10, 2011

Musgrave, Richard dan Peggy, 1993, Public finance in theory and Practice, Mc Graw- hill, Inc Fifth edition London

O'sullivan, 2007, Models for human capital management human resources managemen of intellectual capital, New York Institute of Technology

, OJK, 2015, Potensi pertumbuhan ekonomi ditunjau dari penyaluran kredit perbankan kepada sektor prioritas ekonomi pemerintah, Departemen Pengembangan Pengawasan dan Managemen Krisis

Payaman, J, 1998, Pengantar ekonomi sumberdaya manusia, Jakarta, LPFE UI

Peacock, 1965, Toward a theory of inter regional fiscal policy, public finace, Vol. 29

Porter, 2000, Location, Competition and economic dev local clusters in a global economy, Economic dev quarterly 14 (1), 15 - 34 
Porter, 1998, Clusters and the new economic of competition, Harvard business Review

Porter, 1990, The competitive advantage of nations, Macmilian, London

Rudenno, 2004, The mining valuation handbook, $2^{\text {nd }}$ edition, Rightbooks an import of john willey and sons Austrlia, Ltd 2012, kajian Supply dan Demand mineral, Pusat data dan informasi, Kementerian ESDM RI

Sadono, 2000, Pengantar teori makroekonomi, PT. Raja Grafindo Persad, jakarta

Salebu, Jefry Batara 2014, The impact of foreign derict investment on Indonesianeconomic growtn, MPRA paper No. 728302016

Smith, 1977, Growth and Its disorder

Smith, Adam, 1776, An Inquirt into nature and causes of the weatlth of nations, www.feedbooks.com

Solow, Robert M. 1956, A Contribution to the theory economic growyh, the quarterly journal of economic, vol 70 no.1

Sugiyono, 2010, Metode penelitian dan pendidikan pendekatan kualitatif, kuantitatif dan R and D, Alfaresa, Bandung

Suseko, 2011, Analisis pengembangan ekonomi wilayah prov. Sulawesi Tenggara berbasis pertambangan, PPTMB, jurnal TekMIRA

Suyanto, 2011, Perkembangan bisnis dan industri Indonesia 1970 - 2010, Jurnal ilmiah sosial dan humaniora vo. 4 no,1, fakultas bisnis dan ekonomika, unit Surabaya

Tambunan, 2001, Perekonomian Indonesia, Teori dan temuan empiris, galian Indonesia, Jakarta

Todaro, 2000, Economic development seventh edition, Longma Inc, England

Todaro, 1994, Pembangunan ekonomi di dunia ketiga, cetakan ke 4, PT, Bumi Aksara, Jakarta

Uchenna dan Evans, 2012, Governments expenditurein Nigeria, An examination of tri theoretical mantras

Undang-Undang No. 4 tahun 2009 Tentang Pertambangan mineral dan batubara

Wiriosudarmo, 2000, Agenda pertambangan untuk pengembangan kualitas hidup secara berkelanjutan, kerjasama kantor Menteri LH dan UNDP 